\title{
Using Size Class Distributions of Species to Deduce the Dynamics of the Private Urban Forest
}

\author{
Lilian M. Pearce, James B. Kirkpatrick, and Aidan Davison
}

\begin{abstract}
Urban governance in Western societies is increasingly shaped by awareness of the importance of trees in maintaining the environmental function and social livability of cities. Records of change in urban forest composition on public land are generally good. However, a great proportion of trees in western cities occur on private land, where such changes are poorly-documented. The study authors trialed the use of size class analysis, a technique widely used to deduce the dynamics of natural forests, to determine change in the private urban forest. From a sample of blocks in ten suburbs of the Australian cities of Melbourne and Hobart, in which most dwellings have front and back gardens, researchers assessed the implications of changes for the functionality of the urban forest. The height class distributions of a large number of front garden tree taxa were classified. Although the factors affecting height class distributions differ between a natural and an urban forest, those distributions found for most species were so extreme that there was little doubt in interpretation. Tree species that can grow to a large height were under-represented in the smaller height classes, indicating their future decline in the private tree estate. Individuals of glossy-leaved small tree species were over-represented in the smaller height classes, indicating a recent increase in their popularity. The shift toward smaller, denser trees on private land has implications for the functions of the urban forest. A higher level of large tree protection on private land and compensation through planting on public land could mitigate impacts.

Key Words. Garden Tree; Species Composition; Species Preference; Street Tree; Suburban Residents; Tree Management; Urban Forest; Urban Plants; Urban Vegetation.
\end{abstract}

Urban trees help maintain the environmental function and livability of cities by providing social (Sullivan et al. 2004; Elmendorf 2008), psychological (Milligan and Bingley 2007; Nordh et al. 2011), health (Lovasi et al. 2008; Morris and O’Brien 2011), economic (Donovan and Butry 2011; Millward and Sabir 2011), biophysical (Dobbs et al. 2011; Pataki et al. 2011), and biological (MacGregor-Fors 2008; Goddard et al. 2010) benefits. These benefits have motivated efforts to manage cities as coupled social-ecological systems (Alberti 2009; McGrath and Pickett 2011; Pickett et al. 2011), particularly in relation to a recent planning focus on green infrastructure (Wright 2011; Young 2011) and requirements for development contributions towards green space and compensation for tree amenity loss (City of Melbourne 2011).

Urban forestry has only recently gained ground in Australia, despite the pioneering advocacy of John French (1975). A notable step toward embedding urban forestry in municipal land management came in 2003 with the adoption of an urban forest policy by the Local Government Association of New South Wales, although this arguably failed to lead to initiatives on the ground. More recent practical steps include the publication of urban forest strategies by North Sydney Council (2011) and the City of Melbourne (2011). These initiatives reflect considerable, if largely undocumented, advances in the professionalization of arboriculture in Australia over the past twenty years. Amongst the drivers behind this transformation of urban tree management, concern about drought, climate change, the urban heat island effect, and urban sustainability have been prominent (Shears 2009; City of Melbourne 2011). Tree species differ markedly in their suitability for these and other purposes; for example, native bird species conservation is encouraged by both native trees and a subset of exotic trees (Daniels and Kirkpatrick 2006b), and large deciduous trees are particularly useful in-house temperature regulation, while often not being particularly frugal with water consumption.

Municipal land managers employ increasingly sophisticated tools for urban forest mapping, monitoring, and valuation to achieve their goals of increasing the size and health of the urban forest (Myeong et al. 2001; McPherson et al. 2005; Soares et al. 2011; Wu et al. 2008). Knowledge of compositional changes in the public tree estate can usually be expected as a product of this planning and management process. The complementary private tree estate is substantial in many urban areas (Clark et al. 1997; Heynen and Perkins 2005). Knowledge of compositional change in the private urban forest is more difficult to obtain. There is some scope to monitor change using historic and contemporary remote sensing imagery, but discrimination between trees is generally only possible at the life form, rather than at generic or specific levels (Kirkpatrick et al. 2011). The dynamics of natural forests have long been widely deduced using size class analysis (Colinvaux 1993). The size of all individuals of all tree species at a site is measured. If a histogram for a particular species showing number of individuals in each class on the $\mathrm{y}$ axis and class on the $\mathrm{x}$ axis is reverse-J-shaped (i.e., number 
of individuals in a class declines as tree size become larger), it is assumed that the species constantly produces seedlings most of which suffer mortality at various stages before reaching maturity. This inferred continuous recruitment contrasts with the episodic recruitment that is implied by a lack on individuals in the small size classes. If, as in the cases of Eucalyptus spp. and Callitris rhomboidea at Paradise Gorge in Tasmania, Australia (Harris and Kirkpatrick 1991), one species (Eucalyptus) has individuals only in the larger size classes, and the other (Callitris) demonstrates a reverse-J curve, it is reasonable to deduce that in the continued absence of disturbance suited to the regeneration of Eucalyptus, the stand will be dominated by Callitris. By extension, in the urban forest a reverse-J curve could indicate that the species has enjoyed continuing popularity among private residents, while a gap in the smaller size classes could indicate that the species is no longer planted. The causes of natality and mortality in urban trees are likely to be very different to those in natural forests, and so researchers might expect other patterns of size class distribution than the two described here.

In the present paper, size class analysis was applied to contribute to an understanding of the role of private residents in shaping the dynamics of the urban forest in ten suburbs in Melbourne and Hobart, two southeastern Australian cities in temperate climates with populations of 4 million (Melbourne) and 220,000 (Hobart) people. After assessing the suitability of the method, researchers deduce the major compositional changes that are taking place. The authors then speculate on the reasons for these changes and discuss their ecological, social, and functional implications.

\section{METHODS}

\section{Data Collection}

Five suburbs each in the cities of Melbourne $\left(37^{\circ} 47^{\prime} \mathrm{S}\right.$, $\left.144^{\circ} 58^{\prime} \mathrm{E}\right)$ and Hobart $\left(42^{\circ} 52^{\prime} \mathrm{S}, 144^{\circ} 58^{\prime} \mathrm{E}\right)$ were chosen to represent a wide range of socioeconomic and settlement characteristics (Table 1). There is considerable variation in household income and educational status in the sample, the extremes being Albert Park and Malvern at the high end and Risdon Vale at the low end (Table 1). The inner suburbs of Fairfield, Albert Park, and North Hobart largely consist of Victorian era conjoined or ter- race houses, typically $100-150 \mathrm{~m}^{2}$ with small front gardens and larger back gardens. Block size is small compared to the outer suburbs, many of which had substantial native vegetation cover as recently as 1961 (Table 1). Outside the Victorian era suburbs, the typical residence is a single-story, detached dwelling, typically 150-200 $\mathrm{m}^{2}$, sitting on the middle of its allotment. Front and back gardens are typically substantial. Ten blocks within each suburb were selected randomly as this number was enough to typify the suburb. An average suburban block in Melbourne and Hobart contains 40 dwellings.

Tree species were defined as woody species that attain a height of $8 \mathrm{~m}$ or greater on maturity following the most widely used Australian structural classification (Specht 1972). In some cases, it was notpossible to consistently distinguish between related species when viewing them from public spaces. These species were aggregated into groups of species with similar appearance for analysis. In most cases, this aggregation took place at the generic or family levels. In each block, all individuals of all tree species or species groups visible from streets or laneways were recorded in one of the following height classes: $<1.5 \mathrm{~m}, 1.6-3 \mathrm{~m}, 3.1-5 \mathrm{~m}, 5.1-8 \mathrm{~m}$, and $>8 \mathrm{~m}$ (hereafter referred to as: $<1.5 \mathrm{~m}, 1.5-3 \mathrm{~m}, 3-5$ $\mathrm{m}, 5-8 \mathrm{~m}$, and $>8 \mathrm{~m}$ ). The height classes were selected to enable easy estimation by reference to adjacent houses and fences and to incorporate two commonly used lower height limits for trees, $5 \mathrm{~m}$ and $8 \mathrm{~m}$. The rationale for recording individuals in height classes was that within a taxon, taller individuals are likely to be older than shorter individuals. Thus, a predominance of tall individuals over shorter ones indicates that a tree taxon was planted more so in the past than the present, and a predominance of shorter over taller individuals indicates that a tree taxon was planted more in recent years than in earlier years. These inferences can be used to predict the general nature of compositional change in the urban forest, once differences in growth rate and mature tree height are taken into account.

Each tree was noted to be from one of front gardens, back gardens, streets, or other public land. In the case of back gardens, it was only possible to consistently record individuals $>8 \mathrm{~m}$ tall. Therefore any visible, shorter individuals were not used in backyard analyses.

Table 1. Characteristics of suburbs (Bureau of Statistics 2008), in Melbourne (VIC) and Hobart (TAS), Australia.

\begin{tabular}{|c|c|c|c|c|c|c|c|}
\hline Suburb & $\%$ Aus born & $\%$ renting & $\begin{array}{l}\text { Median household } \\
\text { weekly income } \\
\text { (AUD\$) }\end{array}$ & $\begin{array}{l}\% \text { residents } \\
\text { tertiary educated }\end{array}$ & $\begin{array}{l}\text { Mean block } \\
\text { size } 2006\left(\mathrm{~m}^{2}\right)\end{array}$ & $\begin{array}{l}\% \text { blocks with } \\
\text { house in } 1961\end{array}$ & $\begin{array}{l}\% \text { blocks bush } \\
\text { in } 1961\end{array}$ \\
\hline Fairfield $^{z}$ & 71 & 39 & 1046 & 33 & 487 & 100 & 0 \\
\hline Albert Park & 74 & 42 & 1619 & 41 & 268 & 94 & 0 \\
\hline Croydon $^{z}$ & 80 & 25 & 934 & 18 & 953 & 27 & 20 \\
\hline Clayton $^{z}$ & 33 & 54 & 736 & 30 & 666 & 67 & 0 \\
\hline Malvern $^{z}$ & 75 & 27 & 1720 & 40 & 573 & 94 & 0 \\
\hline Sandy Bay ${ }^{y}$ & 73 & 33 & 1082 & 37 & 819 & 72 & 6 \\
\hline North Hobart ${ }^{y}$ & 81 & 50 & 947 & 31 & 473 & 94 & 0 \\
\hline Lenah Valley ${ }^{y}$ & 86 & 22 & 1062 & 24 & 729 & 24 & 35 \\
\hline South Hobart ${ }^{y}$ & 82 & 36 & 963 & 35 & 1464 & 69 & 18 \\
\hline Risdon Vale ${ }^{y}$ & 89 & 27 & 637 & 3 & $*$ & $*$ & $*$ \\
\hline
\end{tabular}

${ }^{\mathrm{z}}$ Melbourne suburbs.

${ }^{y}$ Hobart suburbs.

Note: Asterisk (*) indicates data were not available for Risdon Vale, as it was collected via aerial photographs for each of the other suburbs by Kirkpatrick et al. (2011). 


\section{Data Analysis}

Tree species were classed as fast-growing or slow-growing on the basis of the descriptions in Botanica (2001). The upper value in the mature height range given for each species in Botanica (2001) was used in analyses as potential height, except where field observation suggested a higher value. The potential height for a species group was the potential height of the most commonly planted species. To determine the influence of tree characteristics on height class distributions, researchers tested whether growth rate or potential height affected either the number or proportion of individuals in the $<3 \mathrm{~m}$ and $>8 \mathrm{~m}$ height classes, using Pearson's product moment correlation coefficient.

A 'weed' tree was defined as an exotic invader of native vegetation in the region, whether or not it was sold to the public as a cultivated plant. Weeds, along with many native and exotic ornamentals, self-establish in gardens. The ornamentals were defined as species grown or retained for human purposes other than food production. Native ornamentals were defined as species that occurred in Australia before British occupation in 1788, and planted or retained for human purposes other than food production. Food trees were defined to be those that produce fruit, bark, or leaves consumed by humans.

The species were classified in order to allow the researchers to be able to generalize size class distribution patterns. The percentages of front garden trees in each height class were used as the inputs for an agglomerative classification of the tree species using Euclidean distance and Ward's method. The latter method avoids the chaining that results from the group averaging procedure. The dendrogram and error values were examined to determine the appropriate number of groups. One-way analysis of variance (ANOVA) was used to determine if classificatory groups differed at $P$ $<0.05$ in the potential heights of their component taxa and whether fast-growing trees differed from slow-growing trees in their percentages in each height class. Pearson's product moment correlation coefficient was used to test the strength of linear relationships between potential height and both numbers and proportions of individuals in each height class.

\section{RESULTS}

The data indicated that private trees dominated the urban forest in the suburbs. In Melbourne, there was an almost even distribution of $>8 \mathrm{~m}$ tall trees between the street, front garden, and back garden. In Hobart, a majority of tall trees occurred in private gardens (Table 2). In both cities, the proportions of trees on public spaces, which included small parks, school grounds, and church grounds, were low. A low percentage of trees were located in the streets in the Hobart suburbs (Table 2).

Fifteen taxa (species or species groups) were observed 100 or more times as plants $<3 \mathrm{~m}$ tall (Appendix). Ten of these were taxa that had a height potential that just qualified them to be considered as trees. In contrast, only Betula, Eucalyptus, and Cupressaceae, all of which were potentially tall taxa, had more than 100 individuals in the $>8 \mathrm{~m}$ height class (Appendix).

The trees in group 4, including Acmena spp., Michelia spp., Magnolia grandiflora, and Leptospermum spp., had high proportions of individuals in the smaller height classes and few in the larger height classes (Figure 1), indicating recent planting. In contrast, the trees in group 3, such as Liquidambar styraciflua, Schinus molle, and Eucalyptus spp., were concentrated in the taller height classes with few individuals in the shorter classes (Figure 1 ), indicating popularity in the past, but a lack of recent planting. Groups 1 and 2 were characterized by high percentages in the medium height classes. Group 1 had a smaller percentage of the two lowest height classes than group 2, and group 2 had smaller percentages than group 1 in the 3-5 $\mathrm{m}$ and 5-8 $\mathrm{m}$ height classes (Figure 1). The species that were the strongest outliers from other species for the ratio $>5 \mathrm{~m}:<3 \mathrm{~m}$ trees were in groups 1 and 3, while the outliers for the ratio 3-5 m: 1-3 m trees were all in group 1 (Figure 2). Fastgrowing trees did not differ (ANOVA, $P>0.05$ ) from slower-growing trees in their percentages in any height class.

The potential height of the tree taxa varied significantly by group (ANOVA, $\mathrm{F}=16.85$, d.f. $=3, P<0.001, \mathrm{r}^{2}=44 \%$ ), with taxa in group 3 being potentially much taller than trees in the three other groups (group 1 mean $=12.5 \mathrm{~m}$, s.d. $=6.3$ $\mathrm{m}$; group 2 mean $=12.0 \mathrm{~m}$, s.d. $=6.3 \mathrm{~m}$; group 3 mean $=$ $26.7 \mathrm{~m}$, s.d $=9.8 \mathrm{~m}$; group 4 mean $=12.7 \mathrm{~m}$, s.d. $=6.4 \mathrm{~m}$ ).

Table 2. Percentages of $>8 \mathrm{~m}$ tall trees in different locations, sorted by suburb and city.

\begin{tabular}{|c|c|c|c|c|c|}
\hline Suburb & $\mathrm{N}$ & $\%$ street & $\%$ front & $\%$ back & $\%$ public spaces \\
\hline \multicolumn{6}{|l|}{ Melbourne } \\
\hline Fairfield & 231 & 24 & 29 & 37 & 10 \\
\hline Albert Park & 168 & 64 & 16 & 19 & 1 \\
\hline Croydon & 467 & 15 & 42 & 39 & 4 \\
\hline Clayton & 209 & 22 & 35 & 43 & 0 \\
\hline Malvern & 245 & 33 & 44 & 23 & 0 \\
\hline \multicolumn{6}{|l|}{ Hobart } \\
\hline Sandy Bay & 418 & 1 & 46 & 49 & 4 \\
\hline North Hobart & 227 & 7 & 37 & 47 & 9 \\
\hline Lenah Valley & 186 & 7 & 40 & 47 & 5 \\
\hline South Hobart & 225 & 9 & 38 & 47 & 6 \\
\hline Risdon Vale & 8 & 0 & 87 & 13 & 0 \\
\hline \multicolumn{6}{|l|}{ City } \\
\hline Melbourne & 1320 & 31 & 33 & 32 & 3 \\
\hline Hobart & 1064 & 5 & 50 & 41 & 5 \\
\hline
\end{tabular}


The potential height of tree species was positively related to both their number $(\mathrm{r}=0.42, P<0.001)$ and proportion $(\mathrm{r}=0.68, P<0.001)$ in the $>8 \mathrm{~m}$ height class. There was no relationship between numbers in the $<3 \mathrm{~m}$ height class and potential height $(\mathrm{r}=-0.08, P=0.492)$, and a negative relationship between the percentage of trees in the class and potential height $(r=-0.33, P=0.005)$.

\section{DISCUSSION}

\section{Private and Public Tree Comparison}

The private garden tree estate constituted a much higher percentage of individuals $(78 \%)$ than in the few other cities for which data are available (Clark et al. 1997; Heynen
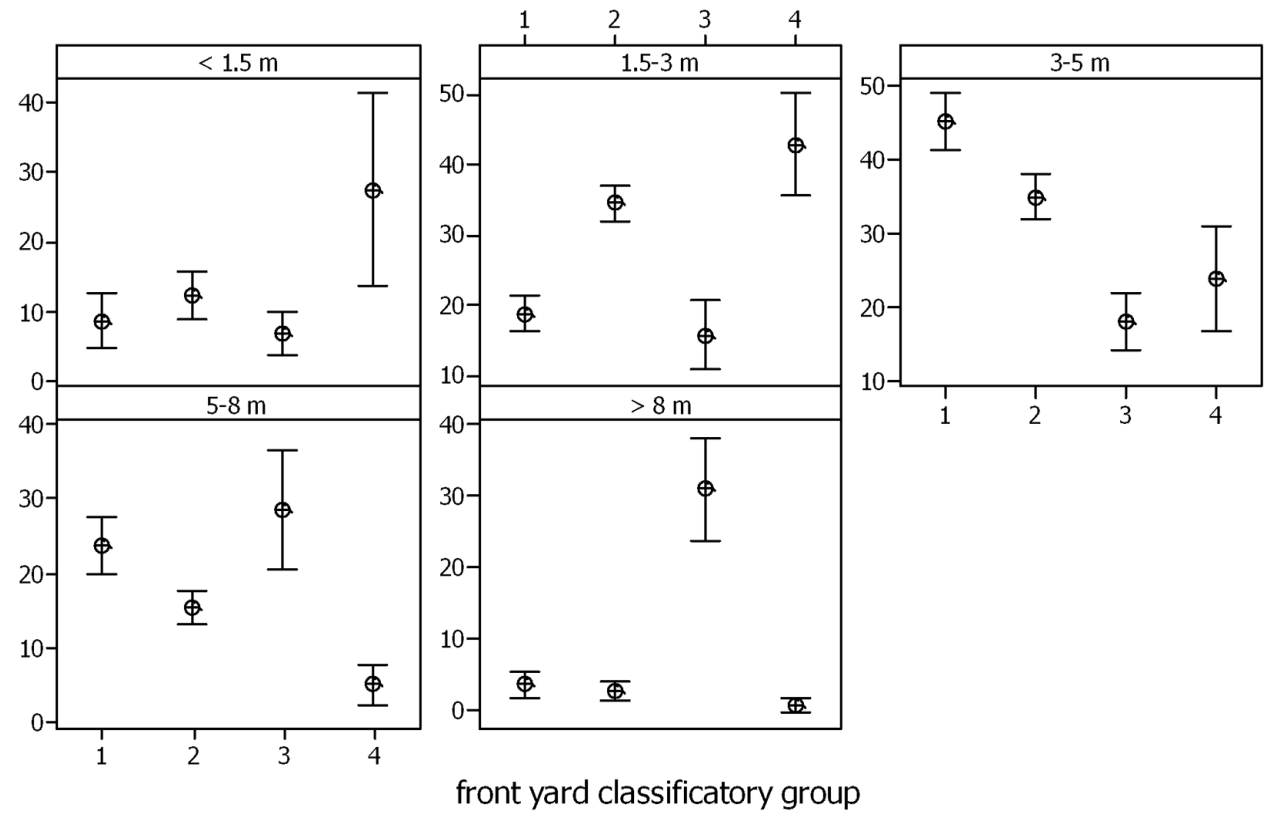

Figure 1. The percentage ( $y$ axis) of specimens in each of the five size classes for the four classificatory groups ( $x$ axis) derived from front garden taxa size class analysis, with mean and $95 \%$ confidence intervals shown.

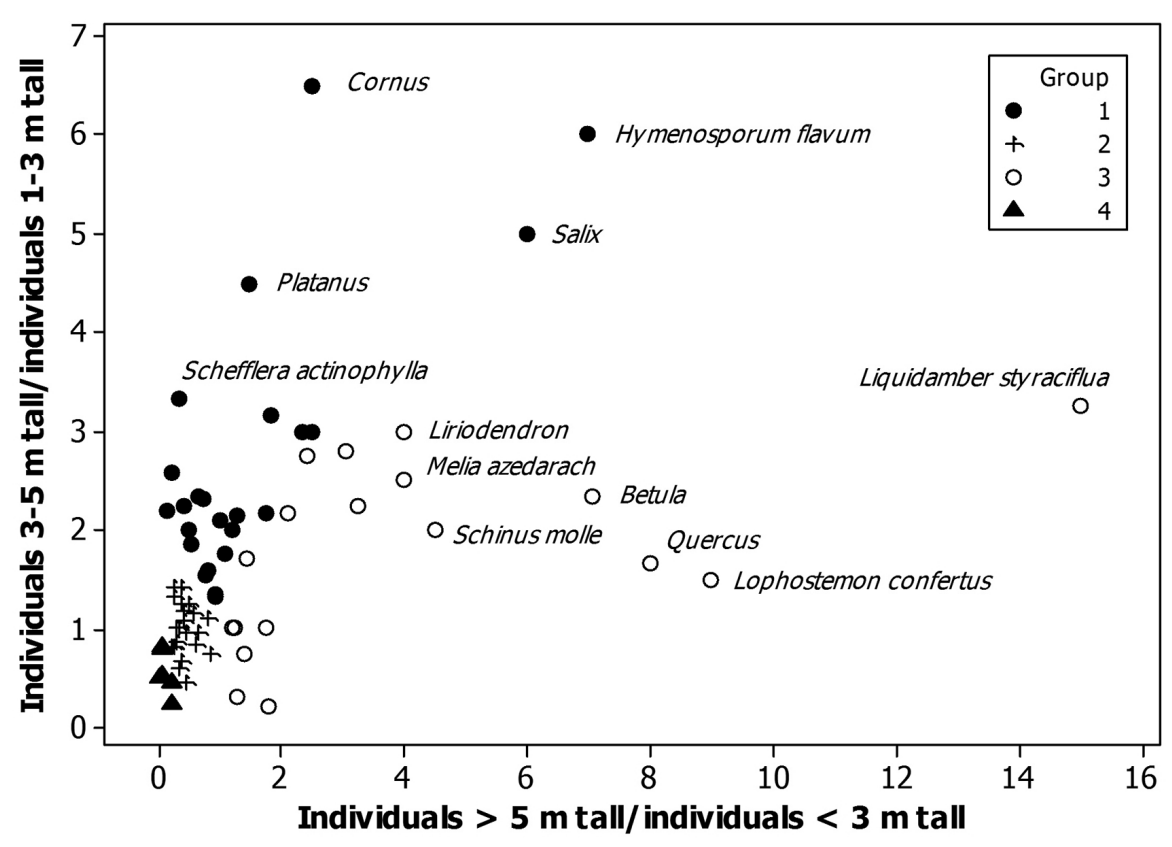

Figure 2. The distribution of species in the four front garden species groups on two ratios of height classes, giving the names of outliers. The ratios of height classes on the axes were selected to give the maximum discrimination between the height-class distribution groups. 
and Perkins 2005). The high proportion of large trees on private land in the current sample emphasizes the importance of understanding the dynamics of the private tree estate.

\section{Size Class Analysis as a tool to Deduce Urban Tree Dynamics}

Urban trees in private gardens are less limited by soils and climate than in natural systems, as gardeners can and do provide supplementary water and nutrients as well as, in some cases, sheltering of young trees from common causes of mortality, such as severe frost and drying winds. This nurturing could be expected to result in lower mortality in age classes, resulting in much flatter reverse-J curves than in a natural forest, as could the lesser competition for space.

Given their nurturing, if garden trees are left to grow as they will, height is a good surrogate for age. However, height is subject to modification by the gardener, who may remove the tops of trees for various reasons, and many of whom use tree taxa for hedging and topiary, although both phenomena are uncommon. Taxa pruned for these purposes include Cupressus macrocarpa, Photinia glabra, and Camellia species. In the cases of the self-seeding taxa, such as Cotoneaster spp., Pittosporum undulatum, and Prunus spp., their voluntary nature and their tendency to be a nuisance in adjacent bushland can lead to an early demise (Zagorski et al. 2004). This truncation of their potential lifespan may concentrate their incidence in the classes of lesser stature. The recent tendency to plant advanced tree stock also complicates interpretation of the data set.

The fact that there was no relationship between growth rate and height class distribution removes one possible difficulty in the interpretation of the results. Small proportions of individuals in the smaller height classes can therefore be most reasonably interpreted as a recent failure to plant potentially tall trees rather than the result of any particularly rapid transition from seedling to $8 \mathrm{~m}$ tall tree.

\section{The Changes}

The size class distribution data strongly suggested that the private urban tree estate will change in its species composition over the coming decades. The study authors are confident that these changes are real because there are many species of trees that lack, or almost lack, representation in the smallest height class, and many others that lack, or almost lack, representation in the largest height class. It is inferred that the former species are not being planted at a sufficient rate to maintain their present density as mature trees, and that the latter will become more prominent in the tallest class in the future.

A prime example of species in the former class is the slowgrowing Liquidambar styraciflua (Figure 2). The general pattern is a downward trend for the potentially tall exotic trees, such as the deciduous trees, Larix spp., Quercus spp., Ulmus spp., Fraxinus spp., and Liquidambar styraciflua, and the evergreen Picea spp., and Pinus spp. (Figure 2). The native rainforest tree Grevillea robusta is also not prominent in the smaller height classes. Tall forest trees have given way to glossy-leaved small trees, such as Magnolia grandiflora and Michelia species. Although some of these species are widely used as hedging plants, most are also planted as specimen trees, and some, such as Michelia, were not observed by us in hedges.
None of the four groups of trees possessed a reverse-J curve, on average. Although trees in group 4 came closest, their greatest density is in the second smallest class rather than the smallest (Figure 1). The patterns in all four groups are typical of the patterns shown in episodic recruitment in natural forests (Figure 1).

\section{Explaining Private Tree Preferences}

Researchers postulate the following possible explanatory factors for the observed shifts in private tree species composition: the vagaries of fashion consequent on the increased influence of garden-related industries and popular media on private tree choices; shifts in cultural meanings invested in urban trees ranging from issues of belonging to perceptions of risk; biophysical drivers, such as drought and diseases; and changes to housing trends and urban form, leading to reduced provision of private garden space.

In the 1950s, the ornamental trees for front yard display that were most favored by homeowners and stocked by nurseries in Melbourne were Liquidambar sp. and Betula sp., while the Cupressaceae family and Photinia robusta were used for tall hedges (Kirkpatrick 2006). Today glossy-leaved evergreen trees, preferably with spectacular or interesting flowers or fruits (e.g., Acmena spp. Magnolia grandiflora, Michelia doltsopa) or plants with unusual foliage color(e.g., Pittosporum tenuifolium) are being used as accents. This shift is likely to have been influenced by the increasing scale of garden-related economic consumption over the past fifty years allied to the growth of private garden industries, chiefly nursery, maintenance, landscaping, and arboricultural businesses.

In the second half of 2009, the Australian garden nursery and garden maintenance industries alone accounted for a turnover of AUD 3.8 billion (NGIA/HA 2010). The increased economic importance of garden consumption has been accompanied by increased investment in tree-related advertising and significant growth in gardening content in popular media, such as television programs and magazines (NGIA/ HA 2010). While responding to resident tree species preferences, this market activity explicitly seeks to influence consumer demand and, in particular, to promote novelty and changing fashion as mechanisms of sustaining the consumption of tree 'products' in the face of the longevity of many trees. This activity raises the prospect that many healthy trees may be removed at a frequency dictated by the vagaries of fashion (Kirkpatrick et al. 2012). It is interesting to note that currently the most highly fashionable trees, those in group 4 , are among those that demand the greatest amounts of water, suggesting that such fashion is not necessarily attuned to environmental conditions. This finding is indeed remarkable in the Melbourne context, as the city experienced prolonged drought through most of the first decade of this century, leading to water restrictions, increased water prices and government education programs aimed at promoting 'water-wise gardening.' Interestingly, the desire for water efficiency in plants is conflicted by a converse preference for broad leaved, dense canopy trees, which, due to their shade and high levels of evapotranspiration, cool cities (City of Melbourne 2011).

In cities and elsewhere, trees are carriers of cultural meaning (Jones and Cloke 2002). Thus, changes in tree preferences are likely to reflect underlying cultural shifts. The finding that recent tree plantings (group 4) are likely to provide better privacy than earlier, tall-tree plantings is in keeping with the de- 
creasing cultural importance of gardens as bearers of cultural conformity (see Timms 2006) and their increasing importance as sources of privacy and as sites in which to express individuality (Daniels and Kirkpatrick 2006a; Kirkpatrick et al. 2009).

The intensifying of a risk avoidance and public liability culture over the past twenty years in Australia has reduced the attractiveness of large (especially brittle) trees to residents, not least because of increased maintenance costs. Planting guides suggest that cypresses and eucalypts unpredictably drop large limbs, while paperbarks and wattles are also prone to collapse at a relatively young age. Additionally, the impact of the Victorian bushfires in the summer of 2009 and the subsequent amendments to the planning scheme as a result may have influenced homeowner perception of fire risk from trees (Kirkpatrick et al. 2012).

Perhaps the most significant ways in which trees bear cultural meaning in Australia is in relation to questions of place and belonging (Holmes et al. 2008), questions that run deep in colonial societies (Kirkpatrick 2006). The latter part of the twentieth century saw a surge of expression of nativism in urban gardens in Australia (Timms 2006; Head and Muir 2007). Some gardeners restricted their tree palette to natives, or local indigenous species, while others used natives in combination with exotic trees (Daniels and Kirkpatrick 2006a; Kirkpatrick et al. 2007; Kendal et al. 2012). This shift is reflected in the data, particularly in the prevalence of bottlebrushes (Callistemon spp.), native trees that flower profusely, do not grow too tall, and rapidly form dense, obscuring foliage (see Appendix). Habitat gardening is an emerging private garden ideology directed toward the succor of native birds, reptiles, frogs, and mammals (Grant 2003). Large trees provide better and more habitat for many native species than an equivalent area of smaller trees, shrubs, or lawn (Stagoll et al. 2012). Although native animal species use many exotic trees for food and shelter (Low 2003; Daniels and Kirkpatrick 2006b), habitat gardeners tend also to be nativists of the local variety. However, habitat gardeners are too rare in suburbia to have much influence, judging by the very small incidence of complex native gardens in Hobart suburbs (Kirkpatrick et al. 2007).

Changing environmental values have also seen increased uptake of chemical-free, productive gardening in Australian cities, sometimes under the banners of organic gardening or permaculture (Timms 2006). This change has recently seen the longstanding habit of planting fruit trees in Australian backyards extended to front gardens (Kirkpatrick et al. 2007).

Several biophysical factors are likely to be implicated in the observed tree species composition. The droughts and heat waves of the 1990s and 2000s resulted in morbidity and mortality of a wide variety of trees (Kendal 2011). For example, personal observations on the part of the authors suggest that there was widespread mortality of Camellia spp. and Betula spp. in Melbourne during the February 2009 heat wave, and the city's dominant CBD tree, Platanus, suffered greatly (City of Melbourne 2011). Pests and pathogens have also led to the loss and reduced planting of some species (e.g., Ulmus spp. in Melbourne, Acacia iteaphylla in Hobart). The recently introduced myrtle rust may threaten a large proportion of the garden trees of Melbourne, particularly natives. Pine and cypress trees may have become unpopular because they provide excellent breeding habitat for the native brush-tailed and ring-tailed possums, which in turn feed on suburban fruit trees, exotic ornamentals (e.g., roses and camellias), and vegetable crops (Kirkpatrick 2006). These biophysical factors highlight a vulnerability that comes with relying on a few species of trees.

The trend toward smaller urban trees is also a reflection of the changing physical structure of the urban environment. There has been a marked increase in the residential density of Australian cities over recent decades (Beeton et al. 2006). This closer settlement has been achieved with the subdivision of existing suburban plots and the building of new houses on smaller lots. Coupled with a significant increase in the size of Australian homes, these changes have seen the extent of private garden space reduced considerably (Hall 2010). Combined with heightened interest in risk avoidance, this trend toward smaller gardens militates against the planting of tall trees. The recent uptake of rooftop solar power systems in suburbs and the growing trend for vegetable gardening are likely to further contribute to the planting of smaller trees.

The trend toward shorter stays in individual residences, whether renting or owning, is also likely to contribute to a shift away from slower growing, larger, and long-lived tree species. Given the eight-year mean turnover of house residency (ABS 2009), planting a tree that takes decades to reach a substantial height requires selflessness and foresight.

\section{Planning and Management Implications}

Changes in the species composition of the private tree estate reported here have important implications for management efforts to optimize the social and environmental benefits afforded by the urban forest. The finding that large trees are likely to be less common in private gardens than in the past is especially significant as large trees are widely regarded to deliver a disproportionate share of urban forest benefits (Moore 2009). For example, large trees tend to become independent of watering by humans as their roots gain access to groundwater, provide vital urban habitat for many native animal species, and may figure more prominently than small trees in social processes of placemaking (Wolf 2005), as they are highly visible in the landscape and are experienced as shared characteristics of a local place. Moreover, the challenging conditions and space constraints experienced by street trees mean that unless new and novel opportunities to plant large trees in public spaces (such as in the roadway) are afforded, the population of large trees will continue to decline. The canopy cover targets that are commonly used to indicate urban forest benefits by municipal tree managers will be considerably harder to deliver with a smaller private tree stock.

An important management context for such canopy cover targets is the potential for anthropogenic climate change to exacerbate urban heat island effects (e.g., City of Melbourne 2011), thereby posing risks to public health and well-being, built infrastructure, and urban biodiversity, amongst others. In this context it needs to be noted that the large deciduous trees in group 3, if properly situated in relation to adjacent housing, are known to moderate extremes of temperature and humidity and thereby lower domestic energy consumption. The replacement of these trees by the smaller species in group 4 , along with the potential heating effects of increases in the built fabric, raises the prospect of positive feedback between increased domestic energy consumption, global climate change, and local urban heat island effects (Hamin and Gurran 2009; Kendal 2011). Additionally, carbon storage by large trees is up to 1000 times greater than 
that of small trees (McPherson et al. 1994). The shade provided by large canopy trees, both on public and private properties where the tree overhangs public space, modifies the local microclimate, reducing temperature and encouraging pedestrians and cyclists, thus influencing public health (City of Melbourne 2011).

Since the early 1980s, municipal governments in Hobart, unlike the majority in Melbourne, have employed UK-style tree preservation orders as a way of protecting larger trees on private as well as public land. The data does not directly answer the question of whether and to what extent healthy large trees have been removed from private gardens; the data does, however, suggest that such regulations may not have been effectively enforced in Hobart. It is possible that public resentment toward local government controls over private trees may be a factor in encouraging residents to plant smaller trees or to remove trees to pre-empt restrictions. In this context, researchers note that the City of Melbourne is currently developing a register of exceptional trees on private property with the intention of protection through the Melbourne Planning Scheme. The study authors also note that regulation has been shown to be effective in retaining large private trees in at least one western city (Sung 2012).

While managers have a growing range of regulatory instruments at their disposal, the mandated planting of certain types of trees on private land is politically difficult to advocate and virtually impossible to implement. In this context, one management implication of the data is that loss of tall trees in the private estate needs to be compensated for by planting on public land. For example, if the Norfolk Island pines and Canary Island palms that characterize coastal suburbs in Melbourne begin to disappear from gardens, they can be preferentially planted in streets and reserves by municipal land managers. The difficulty here is that use of public space is increasingly contested in Australian cities. Urban consolidation through subdivision of existing blocks, for example, typically reduces the viable room for street trees on the adjacent street verge through the requirement for multiple driveways. Urban consolidation in the form of new developments also typically has lower public space provision as well as smaller setbacks of housing from the street than was the case in most of the twentieth century. Finally, while some Australian suburbs have increased overhead space for large trees by burying power lines, competition for underground space has intensified, not only due to the addition of power lines, but as a result of increased residential densities and the presence of new telecommunications services.

Regulatory approaches are only one way in which public managers seek to influence the tree management practices of private residents. One alternative is to support tree-related industries and councils in educating the public about the systemic benefits of the urban forest and to ensure that there is adequate availability of appropriate tree stock. Related to this is the opportunity to raise public awareness of the invaluable contribution of private trees to the urban forest through education and the celebration of existing trees. This could be supported by increased popular media content about gardening. Recognition of the values of existing trees through such mechanisms as council registers, urban forest art and design competitions, or walking tours may assist in this goal. Furthermore, by offering incentives for the retention of existing trees, such as free arboricultural advice, the contribution of private tree estate to urban forest function may be maintained. Another alternative is to directly engage residents in urban forest management on public land. The potential for such involvement may be particularly high in Australia, where horticultural societies and gardening groups have a strong presence. Community Landcare groups have partnered with government to rehabilitate public bushland over the past few decades (Davison and Ridder 2006). There is little research examining the relationship between participation in these groups and private garden practices. The potential of these groups to raise the awareness of residents about the importance of the private tree estate in urban forest management is not known.

One difficulty facing managers in seeking to educate residents about the importance of their role as private land managers within the urban forest is the dearth of research into the motives, and especially the actions, of private residents in relation to urban trees. Such research may not only identify effective educational and regulatory strategies, but also reveal ways in which private residents are uniquely positioned to contribute to the well-being of the urban forest. Consider, for example, the emerging emphasis on increasing tree species diversity in Australian urban forest management, as a strategy for building resilience in the urban forest in the face of pests, diseases, and environmental change more generally (City of Melbourne 2011; North Sydney Council 2011). In this regard, an observed increased cultural emphasis on individual self-expression through gardening (Kirkpatrick et al. 2009) may be a mechanism by which the species diversity of the urban forest may be maintained. The high proportion of tree cover found in the private realm, and the changing nature of that tree cover as exposed by this study suggests a need to understand the current composition and influencing drivers of private trees. By carrying out collective management of the urban forest that considers the private tree estate, the social, ecological, and environmental benefits afforded by the urban forest will be enhanced.

Acknowledgments. The authors would like to thank Cynnamon Dobbs for comments on an earlier version of this manuscript. This research was funded by ARC grant DP0878249: Patterns, causes and consequences of tree retention, establishment, and removal in Australian Cities.

\section{LITERATURE CITED}

ABS. 2009. Housing Mobility and Conditions 2007-08. Australian Bureau of Statistics 4130.0.0.55.002, Canberra.

Alberti, M. 2009. Advances in Urban Ecology: Integrating Humans and Ecological Processes in Urban Ecosystems. Springer.

Beeton, R.J.S., K. Buckley, G.J. Jones, D. Morgan, R.E. Reichelt, and D. Trewin. 2006. Australian State of the Environment Report 2006: Human settlements, Department of Sustainability, Environment, Water, Population and Communities, Australian Government, Canberra. Accessed 07/26/2011. <www.environment.gov.au/soe/2006/ publications/report/human-settlements-1.html>

Botanica's Trees and Shrubs. 2001. Random House, Australia.

City of Melbourne 2011. Urban Forest Strategy: Making a Great City Greener, 2012-2032. Consultation Draft. City of Melbourne, Melbourne, Victoria, Australia.

Clark, J.R., N.P. Matheny, G. Cross, and V. Wake. 1997. A model of urban forest sustainability. Journal of Arboriculture 23(1):17-30.

Colinvaux, P. 1993. Ecology 2. Wiley, New York City, New York, U.S.

Daniels, G.D., and J.B. Kirkpatrick. 2006a. Comparing the characteristics of front and back domestic gardens in Hobart, Tasmania, Australia. Landscape and Urban Planning 78:344-352. 
Daniels, G.D., and J.B. Kirkpatrick. 2006b. Does variation in garden characteristics influence the conservation of birds in suburbia? Biological Conservation 133:326-335.

Davison A., and B. Ridder. 2006. Turbulent times for urban nature: conserving and re-inventing nature in Australian cities. Australian Zoologist 33(3):306-314.

Dobbs, C., F.J. Escobedo, and W.C. Zipperer. 2011. A framework for developing urban forest ecosystem services and goods indicators. Landscape and Urban Planning 99:196-206.

Elmendorf, W. 2008. The importance of trees and nature in community: A review of the relative literature. Journal of Arboriculture 34:152-156.

French, J.R.J. 1975. The concept of urban forestry. Australian Forestry 38:177-182.

Goddard, M.A., A.J. Dougill, and T.G. Benton. 2010. Scaling up from gardens: Biodiversity conservation in urban environments. Trends in Ecology and Evolution 25(2):90-98.

Grant, P. 2003. Habitat Gardening. ABC Books, Sydney, Australia.

Hall, T. 2010. The Life and Death of the Australian Backyard. CSIRO Publishing, Melbourne.

Hamin, E.M., and N. Gurran. 2009. Urban form and climate change: Balancing adaptation and mitigation in the U.S. and Australia. Habitat International 33:238-245.

Harris, S., J.B. Kirkpatrick. 1991. The distributions, dynamics, and ecological differentiation of Callitris species in Tasmania. Australian Journal of Botany 39:187-202.

Head, L., and P. Muir. 2007. Backyard. University of Wollongong Press, Wollongong, Australia.

Heynen, N., and H.A. Perkins. 2005. Scalar dialectics in green: Urban private property and the contradictions of the neoliberalisation of nature. Capitalism Nature Socialism 16(1):99-113.

Holmes, K., S.K. Martin, and K. Mirmohamadi. 2008. Reading the Garden: The Settlement of Australia. Melbourne University Press, Melbourne, Victoria, Australia.

Jones, O., and P. Cloke. 2002. Tree Cultures: The Place of Trees and Trees in Their Place. Berg, Oxford, England.

Kendal, D. 2011. Potential effects of climate change on Melbourne's street trees and some implications for human and non-human animals. In: Proceedings of the 2011 State of Australian Cities Conference. Melbourne, Victoria, Australia.

Kendal, D., K.J.H. Williams, and N.S.G. Williams. 2012. Plant traits link people's plant preferences to the composition of their gardens. Landscape and Urban Planning 105:34-42.

Kirkpatrick, J.B. 2006. The Ecologies of Paradise. Pandani Press, Hobart, Tasmania, Australia.

Kirkpatrick, J.B., G.D. Daniels, and T. Zagorski. 2007. Explaining variation in front gardens between suburbs of Hobart, Tasmania, Australia. Landscape and Urban Planning 79:314-322.

Kirkpatrick, J.B., G.D. Daniels, and A. Davison. 2009. An Antipodean test of spatial contagion in front garden character. Landscape and Urban Planning 93(2):103-110.

Kirkpatrick, J.B., G.D. Daniels, and A. Davison. 2011. Temporal and spatial variation in garden and street trees in six eastern Australian cities. Landscape and Urban Planning 101:244-252.

Kirkpatrick, J.B., A. Davison, and G.D. Daniels. 2012. Attitudes to trees influence the planting and removal of different types of trees in eastern Australian cities. Landscape and Urban Planning 107:147-158.

Low, T. 2003. The New Nature: Winners and Losers in Wild Australia. Penguin Books, Australia.
Lovasi, G.S., J.W. Quinn, K.M. Neckerman, M.S. Perzanowski, and A. Rundle. 2008. Children living in areas with more street trees have lower prevalence of asthma. Journal of Epidemiology and Community Health 62:647-649.

MacGregor-Fors, I. 2008. Relation between habitat attributes and bird richness in a western Mexico suburb. Landscape and Urban Planning 84:92-98.

McGrath, B., and S.T.A. Pickett. 2011. The metacity: A conceptual framework for integrating ecology and urban design. Challenges 2(4):55-72.

McPherson, E.G., D.J. Nowak, and R.A. Rowntree. 1994. Chicago's Urban Forest Ecosystem: Results of the Chicago Urban Forest Climate Project. United States Department of Agriculture Forest Service, Radnor, Pennsylvania, U.S.

McPherson, E.G., J.R. Simpson, P.J. Peper, S.E. Maco, and Q. Xiao. 2005. Municipal forest benefits and costs in five U.S. cities. Journal of Forestry 103(8):411-416.

Milligan, C., and A. Bingley. 2007. Restorative places or scary places? The impact of woodland on the mental well-being of young adults. Health and Place 13:799-811.

Millward, A.A., and S. Sabir. 2011. Benefits of a forested urban park: What is the value of Allan Gardens to the city of Toronto, Canada? Landscape and Urban Planning 100:177-188.

Moore, G.M. 2009. Managing trees during climate change. Arborist News 18(6):30-34.

Morris J., and E. O'Brien. 2011. Encouraging healthy outdoor activity amongst under-represented groups: an evaluation of the Active England woodland projects. Urban Forestry and Urban Greening 10(4):323-333.

Myeong, S., D.J. Nowak, and P.F. Hopkins. 2001. Urban cover mapping using digital, high-spatial resolution aerial imagery. Urban Ecosystems 5(4):243-256.

NGIA/HA. 2010. Australian Garden Market Monitory: For the spring period ending December 31, 2009. Nursery and Garden Industry Australia/Horticulture Australia Ltd. Accessed 03/28/2012. <www. ngia.com.au>

Nordh, H., C. Alalouch, and T. Hartig. 2011. Assessing restorative components of small urban parks using conjoint methodology. Urban Forestry and Urban Greening 10(2):95-103.

North Sydney Council 2011. North Sydney Urban Forest Strategy 2011. North Sydney Council, Sydney, Australia.

Pataki, D.E., M.M. Carreiro, J. Cherrier, N.E. Grulke, V. Jennings, S. Pincetl, R.V. Pouyat, T.H. Whitlow, and W.C. Zipperer. 2011. Coupling biogeochemical cycles in urban environments: ecosystem services, green solutions, and misconceptions. Frontiers in Ecology and the Environment 9:27-36.

Pickett, S.T.A., G.L. Buckley, S.S. Kaushal, and Y. Williams. 2011. Social-ecological science in the human metropolis. Urban Ecosystems 14:319-339.

Shears, I. 2009. City of Melbourne: An urban greening perspective. pp. 55-61. In: Proceedings of Conf. on The 10th National Street Tree Symposium, TreeNet, Adelaide, Australia.

Soares, A.L., F.C. Rego, E.G. McPherson, J.R. Simpson, P.J. Peper, and Q. Xiao. 2011. Benefits and costs of street trees in Lisbon, Portugal. Urban Forestry and Urban Greening 10(1):69-78.

Specht, R.L. 1972. Vegetation of South Australia. Government Printer, Adelaide, Australia.

Staggoll, K., D.B. Lindenmayer, E. Knight, J. Fischer, and A.D. Manning. 2012. Large trees are keystone structures in urban parks. Conservation Letters 5:115-112. 
Sullivan, W.C., F.E. Kuo, and S.E. DePooter. 2004. The fruit of urban nature: Vital neighbourhood spaces. Environment and Behavior 36(5):678-800.

Sung, C.Y. 2012. Evaluating the efficacy of a local tree protection policy using LiDAR remote sensing data. Landscape and Urban Planning 104:19-25.

Timms, P. 2006. Australia's Quarter Acre: The Story of the Ordinary Suburban Garden. Miegunyah Press, Melbourne, Victoria, Australia.

Wolf, K.L. 2005. Business district streetscapes, trees, and consumer response. Journal of Forestry 103(8):396-400.

Wright, H. 2011. Understanding green infrastructure: the development of a contested concept in England. Local Environment 2011:1-17.

Wu, C., Q. Xiao, and E.G. McPherson. 2008. A method for locating potential tree-planting sites in urban areas: A case study of Los Angeles, USA. Urban Forestry and Urban Greening 7:65-76.

Young, R.F. 2011. Planting the Living City, Journal of the American Planning Association, 77(4):368-381.

Zagorski, T., J.B. Kirkpatrick, and E. Stratford. 2004. Gardens and the bush: gardeners attitudes, garden types and invasives. Australian Geographical Studies 42:207-220.

Lilian M. Pearce (corresponding author)

School of Geography and Environmental Studies

University of Tasmania

Private Bag 78

Hobart, Tasmania 7001, Australia

The Australian Research Centre for Urban Ecology

Royal Botanic Gardens Melbourne

c/o School of Botany

The University of Melbourne

Victoria 3010, Australia

lm.pearce@unimelb.edu.au

James B. Kirkpatrick

School of Geography and Environmental Studies

University of Tasmania

Private Bag 78

Hobart, Tasmania 7001, Australia

Aidan Davison

School of Geography and Environmental Studies

University of Tasmania

Private Bag 78

Hobart, Tasmania 7001, Australia
Zusammenfassung. Die urbanen Verwaltungen in westlichen Gesellschaften werden zunehmend durch das Bewusstsein über die Bedeutung von Bäumen und ihrer ökologischen Funktion und ihrem Betrag zur Lebensqualität der Städte geprägt. Die Aufzeichnungen über die Veränderungen der Zusammensetzung urbaner Forste auf öffentlichen Flächen sind generell gut. Dennoch kommt eine große Anzahl der Bäume in westlichen Städten auf privatem Gelände vor, wo solche Veränderungen in der Artenzusammensetzung nur schlecht dokumentiert sind. Die Autoren dieser Studie experimentierten mit der Analyse von Größenklassen, eine weit verbreitete Technik, um die Dynamik natürlicher Forste herzuleiten, um die Veränderungen in privaten Forstflächen zu bestimmen. Aus einer Blockprobe in zehn Vorstadtregionen in den australischen Städten Melbourne und Hobart, wo die meisten Siedler einen Vor- und Hintergarten besitzen, untersuchten die Forscher die Auswirkungen der Veränderungen auf die Funktionalität der urbanen Waldflächen. Die Verteilung in verschiedenen Höhenklassen einer großen Anzahl von Baumarten im Vorgarten wurde klassifiziert. Obwohl die Faktoren, die die Höhenklassenverteilung beeinflussen, zwischen den natülichen und urbanen (angelegten) Forstflächen differieren, waren die gefundenen Faktoren für die meisten Arten so extrem, dass keine Zweifel bei der Interpretation bestanden. Baumarten mit großem Höhenwuchspotential waren in den kleineren Höhenklassen unterpräsentiert, was ihren künftigen Untergang in den privaten Geländen bedeutet. Einzelexemplare von kleinen Baumarten mit glänzenden Blättern waren in den kleineren Höhenklassen überpräsentiert, was einen Hinweis auf ihre zunehmende Popularität gibt. Die Bewegung in Richtung kleinere, dichte Baumarten auf privatem Grund hat auch Auswirkungen auf die Funktionen des urbanen Forstes. Ein größerer Grad von Baumschutz für Großbäume auf Privatgrundstücken und Kompensation durch Pflanzungen auf öffentlichem Grund könnte die Auswirkungen mindern.

Resumen. La gobernanza en las sociedades urbanas de occidente está aumentando su preocupación por la importancia de los árboles en el mantenimiento de la función ambiental y social de las ciudades. Los registros del cambio en la composición del bosque urbano en terrenos públicos son generalmente buenos. Sin embargo, una gran proporción de árboles en ciudades occidentales ocurre en terrenos privados, donde tales cambios están pobremente documentados. Los autores del estudio ensayaron el uso de análisis de clases de tamaño, una técnica ampliamente usada para deducir las dinámicas naturales de los bosques, para determinar el cambio en el bosque urbano privado. De una muestra de cuadras en diez suburbios de ciudades australianas de Melbourne y Hobart, en las cuales la mayoría de los propietarios tienen jardines frontales y traseros, los investigadores evaluaron las implicaciones de los cambios para la funcionalidad del bosque urbano. Se clasificaron las distribuciones de clases de altura de un gran número de taxa de árboles de jardines frontales. Aunque los factores que afectan la distribución de las clases de altura difieren entre un bosque natural y un bosque urbano, estos factores encontrados para muchas especies fueron tan extremos que hubo pequeñas dudas en la interpretación. Las especies de árboles que pudieron crecer a mayor altura estuvieron sub-representadas en las clases de altura más pequeñas, indicando su futura declinación en el estado de árbol privado. Los individuos más pequeños, estuvieron sobre-representados en las clases de altura más pequeñas, indicando un incremento reciente en su popularidad. El cambio hacia más pequeños y más densos árboles en terrenos privados tiene implicaciones para las funciones de un bosque urbano. Un alto nivel de protección de árboles grandes en terrenos privados y la compensación a través de la plantación en terrenos públicos podría mitigar los impactos. 


\section{Appendix.}

Percentage of individuals in front gardens in the five height classes by taxon, showing the number of individuals (the highest percentage for each taxon is underlined), the classificatory group, the potential height (Pot ht) and class of tree by taxon. All taxa in the table can grow over $8 \mathrm{~m}$ according to the garden guides or the current measurements. When there is more than one species in a group, the most widely planted species was used for height. A weed is an invader of native vegetation whether cultivated or not. Weeds, along with many exotic and native ornamentals, self-sow in gardens. The exotic ornamentals are non-native species grown for human purposes other than food production. The native ornamentals are species that occurred in Australia in 1788 and are planted for human purposes other than food production. Food trees produce edible fruit, bark, or leaves. For class, $\mathrm{N}=$ native ornamental, $\mathrm{W}=$ weed, $\mathrm{F}=$ food, $\mathrm{O}=$ exotic ornamental.

\begin{tabular}{|c|c|c|c|c|c|c|c|c|c|}
\hline \multirow[t]{2}{*}{ Taxon } & \multirow[t]{2}{*}{$\mathrm{N}$} & \multicolumn{5}{|c|}{ Percentage in each height class } & \multirow[t]{2}{*}{ Group } & \multirow[t]{2}{*}{ Class } & \multirow[t]{2}{*}{ Pot ht } \\
\hline & & $<1.5 \mathrm{~m}$ & $1.5-3 \mathrm{~m}$ & $3-5 \mathrm{~m}$ & $5-8 \mathrm{~m}$ & $>8 \mathrm{~m}$ & & & \\
\hline Exocarpos cupressiformis & 18 & 5.56 & 27.78 & $\underline{61.11}$ & 5.56 & 0.00 & 1 & $\mathrm{~N}$ & 10 \\
\hline Ilex spp. & 49 & $\underline{36.73}$ & 14.29 & $\underline{\underline{36.73}}$ & 8.16 & 4.08 & 1 & $\mathrm{~W}$ & 12 \\
\hline Schefflera actinophylla & 22 & $\overline{27.27}$ & 13.64 & $\overline{45.45}$ & 13.64 & 0.00 & 1 & $\mathrm{~N}$ & 12 \\
\hline Ficus carica & 38 & 15.79 & 21.05 & 47.37 & 15.79 & 0.00 & 1 & $\mathrm{~F}$ & 9 \\
\hline Callitris spp. & 13 & $\underline{30.77}$ & 15.38 & $\underline{30.77}$ & 23.08 & 0.00 & 1 & $\mathrm{~N}$ & 9 \\
\hline Prunus laurocerasus & 139 & $\overline{9.35}$ & 25.18 & $\underline{46.76}$ & 18.71 & 0.00 & 1 & $\mathrm{O}$ & 15 \\
\hline Eriobotrya japonica & 70 & 14.29 & 18.57 & $\underline{42.86}$ & 21.43 & 2.86 & 1 & $\mathrm{~F}$ & 9 \\
\hline Magnolia spp. & 237 & 8.86 & 25.32 & $\underline{38.82}$ & 24.89 & 2.11 & 1 & $\mathrm{O}$ & 12 \\
\hline Acacia spp. & 363 & 14.33 & 21.76 & $\overline{34.44}$ & 24.79 & 4.68 & 1 & $\mathrm{~N}$ & 9 \\
\hline Pittosporum undulatum & 643 & 8.24 & 25.82 & $\underline{33.90}$ & 26.75 & 5.29 & 1 & W & 12 \\
\hline Sambucus spp. & 52 & 5.77 & 26.92 & $\underline{36.54}$ & 28.85 & 1.92 & 1 & W & 15 \\
\hline Lagerstroemia spp. & 96 & 5.21 & 21.88 & $\underline{45.83}$ & 26.04 & 1.04 & 1 & $\mathrm{O}$ & 8 \\
\hline Allocasuarina spp. & 76 & 9.21 & 21.05 & $\overline{36.84}$ & 21.05 & 11.84 & 1 & $\mathrm{~N}$ & 9 \\
\hline Robinia spp. & 21 & 0.00 & 23.81 & 47.62 & 28.57 & 0.00 & 1 & $\mathrm{O}$ & 24 \\
\hline Melaleuca spp. & 239 & 4.60 & 20.08 & $\underline{43.10}$ & 27.62 & 4.60 & 1 & $\mathrm{~N}$ & 9 \\
\hline Platanus spp. & 14 & 0.00 & 14.29 & $\underline{64.29}$ & 21.43 & 0.00 & 1 & $\mathrm{O}$ & 36 \\
\hline Tamarix spp. & 16 & 6.25 & 12.50 & $\underline{37.50}$ & 37.50 & 6.25 & 1 & $\mathrm{O}$ & 9 \\
\hline Sophora spp. & 49 & 2.04 & 14.29 & $\underline{42.86}$ & 30.61 & 10.20 & 1 & $\mathrm{O}$ & 9 \\
\hline Cornus spp. & 20 & 0.00 & 10.00 & $\underline{65.00}$ & 25.00 & 0.00 & 1 & $\mathrm{O}$ & 9 \\
\hline Salix spp. & 12 & 0.00 & 8.33 & 41.67 & 33.33 & 16.67 & 1 & $\mathrm{O}$ & 15 \\
\hline Hymenosporum flavum & 14 & 0.00 & 7.14 & $\underline{42.86}$ & $\underline{42.86}$ & 7.14 & 1 & $\mathrm{~N}$ & 9 \\
\hline Pittosporum tenuifolium & 1260 & 26.51 & 32.30 & $\underline{\underline{26.59}}$ & $\overline{13.57}$ & 1.03 & 2 & $\mathrm{O}$ & 9 \\
\hline Dodonea viscosa & 58 & $\underline{31.03}$ & 29.31 & 24.14 & 15.52 & 0.00 & 2 & $\mathrm{~N}$ & 9 \\
\hline Olea europaea & 188 & 14.89 & 31.38 & $\underline{41.49}$ & 11.17 & 1.06 & 2 & $\mathrm{~F}$ & 9 \\
\hline Bedfordia spp. & 24 & 16.67 & 29.17 & $\overline{41.67}$ & 12.50 & 0.00 & 2 & $\mathrm{~N}$ & 9 \\
\hline Cotoneaster spp. & 549 & 18.21 & 33.15 & $\underline{33.70}$ & 14.03 & 0.91 & 2 & W & 9 \\
\hline Malus spp. & 209 & 7.66 & $\underline{41.63}$ & $\overline{36.36}$ & 13.40 & 0.96 & 2 & $\mathrm{~F}$ & 9 \\
\hline Pistacia spp. & 12 & 16.67 & $\underline{33.33}$ & $\underline{33.33}$ & 8.33 & 8.33 & 2 & $\mathrm{~F}$ & 9 \\
\hline Morus spp. & 11 & 9.09 & 45.45 & 27.27 & 18.18 & 0.00 & 2 & $\mathrm{~F}$ & 12 \\
\hline Hakea spp. & 46 & 19.57 & 26.09 & $\underline{36.96}$ & 17.39 & 0.00 & 2 & $\mathrm{~N}$ & 9 \\
\hline Callistemon spp. & 482 & 11.20 & 31.95 & $\underline{\underline{39.83}}$ & 15.56 & 1.45 & 2 & $\mathrm{~N}$ & 9 \\
\hline Banksia spp. & 97 & 19.59 & $\underline{35.05}$ & 23.71 & 18.56 & 3.09 & 2 & $\mathrm{~N}$ & 15 \\
\hline Photinia glabra & 502 & 1.20 & $\overline{38.05}$ & $\underline{44.82}$ & 13.75 & 2.19 & 2 & $\mathrm{O}$ & 9 \\
\hline Cupressaceae & 1445 & 19.86 & 28.37 & $\underline{\underline{30.59}}$ & 13.84 & 7.34 & 2 & $\mathrm{O}$ & 36 \\
\hline Acer spp. & 457 & 16.85 & $\underline{31.29}$ & 29.98 & 19.04 & 2.84 & 2 & $\mathrm{O}$ & 18 \\
\hline Ficus spp. & 25 & 0.00 & $\underline{52.00}$ & 24.00 & 20.00 & 4.00 & 2 & $\mathrm{O}$ & 18 \\
\hline Prunus spp. & 963 & 8.00 & $\overline{32.09}$ & $\underline{40.19}$ & 17.03 & 2.70 & 2 & $\mathrm{~F}$ & 9 \\
\hline Crataegus monogyna & 37 & 2.70 & 35.14 & $\overline{40.54}$ & 13.51 & 8.11 & 2 & W & 9 \\
\hline Laurus nobilis & 85 & 5.88 & $\underline{36.47}$ & 30.59 & 23.53 & 3.53 & 2 & $\mathrm{~F}$ & 12 \\
\hline Agonis flexuosa & 70 & 5.71 & $\underline{34.29}$ & 32.86 & 22.86 & 4.29 & 2 & $\mathrm{~N}$ & 9 \\
\hline Arboreal Monocots & 272 & 5.51 & $\overline{30.51}$ & $\underline{33.82}$ & 23.90 & 6.25 & 2 & $\mathrm{O}$ & 15 \\
\hline Arbutus unedo & 21 & 0.00 & $\underline{38.10}$ & $\overline{28.57}$ & 23.81 & 9.52 & 2 & $\mathrm{O}$ & 9 \\
\hline Pinus spp. & 27 & 18.52 & 18.52 & 18.52 & $\underline{22.22}$ & $\underline{22.22}$ & 3 & $\mathrm{O}$ & 30 \\
\hline Fraxinus spp. & 123 & 11.38 & $\underline{22.76}$ & $\underline{22.76}$ & $\overline{20.33}$ & 22.76 & 3 & $\mathrm{O}$ & 42 \\
\hline Gleditsia spp. & 26 & 0.00 & 38.46 & 11.54 & 30.77 & 19.23 & 3 & $\mathrm{O}$ & 30 \\
\hline Acer negundo & 30 & 6.67 & 26.67 & 20.00 & 16.67 & $\underline{30.00}$ & 3 & $\mathrm{O}$ & 15 \\
\hline Jacaranda mimosifolia & 51 & 17.65 & 13.73 & 23.53 & $\underline{29.41}$ & $\overline{15.69}$ & 3 & $\mathrm{O}$ & 15 \\
\hline Juglans spp. & 14 & 7.14 & 21.43 & 21.43 & $\underline{28.57}$ & 21.43 & 3 & $\mathrm{~F}$ & 15 \\
\hline Larix spp. & 15 & 0.00 & 33.33 & 6.67 & 13.33 & $\underline{46.67}$ & 3 & $\mathrm{O}$ & 30 \\
\hline
\end{tabular}


Appendix (continued).

\begin{tabular}{|c|c|c|c|c|c|c|c|c|c|}
\hline \multirow[t]{2}{*}{ Taxon } & \multirow[t]{2}{*}{$\mathrm{N}$} & \multicolumn{5}{|c|}{ Percentage in each height class } & \multirow[t]{2}{*}{ Group } & \multirow[t]{2}{*}{ Class } & \multirow[t]{2}{*}{ Pot ht } \\
\hline & & $<1.5 \mathrm{~m}$ & $1.5-3 \mathrm{~m}$ & $3-5 \mathrm{~m}$ & $5-8 \mathrm{~m}$ & $>8 \mathrm{~m}$ & & & \\
\hline Grevillea robusta & 41 & 7.32 & 14.63 & 31.71 & 14.63 & $\underline{31.71}$ & 3 & $\mathrm{~N}$ & 30 \\
\hline Picea spp. & 42 & 11.90 & 9.52 & 26.19 & 14.29 & $\underline{38.10}$ & 3 & $\mathrm{O}$ & 30 \\
\hline Ulmus spp. & 79 & 13.92 & 6.33 & 17.72 & 24.05 & 37.97 & 3 & $\mathrm{O}$ & 45 \\
\hline Eucalyptus spp. & 365 & 9.32 & 9.32 & 20.82 & 22.19 & $\underline{38.36}$ & 3 & $\mathrm{~N}$ & 30 \\
\hline Melia azedarach & 15 & 0.00 & 13.33 & 33.33 & $\underline{40.00}$ & $\overline{13.33}$ & 3 & $\mathrm{~N}$ & 9 \\
\hline Liriodendron spp. & 13 & 7.69 & 7.69 & 23.08 & 30.77 & $\underline{30.77}$ & 3 & $\mathrm{O}$ & 30 \\
\hline Schinus molle & 15 & 0.00 & 13.33 & 26.67 & 33.33 & 26.67 & 3 & $\mathrm{O}$ & 15 \\
\hline Betula spp. & 547 & 1.10 & 8.78 & 20.48 & $\underline{40.95}$ & 28.70 & 3 & $\mathrm{O}$ & 24 \\
\hline Quercus spp. & 50 & 4.00 & 6.00 & 10.00 & $\overline{16.00}$ & $\underline{64.00}$ & 3 & $\mathrm{O}$ & 36 \\
\hline Lophostemon confertus & 23 & 0.00 & 8.70 & 13.04 & 43.48 & 34.78 & 3 & $\mathrm{~N}$ & 30 \\
\hline Liquidambar styraciflua & 125 & 2.40 & 3.20 & 10.40 & $\overline{32.00}$ & $\underline{52.00}$ & 3 & $\mathrm{O}$ & 24 \\
\hline Leptospermum spp. & 51 & 15.69 & $\underline{54.90}$ & 27.45 & 1.96 & $\overline{0.00}$ & 4 & $\mathrm{~N}$ & 9 \\
\hline Citrus spp. & 281 & 24.20 & $\underline{39.86}$ & 32.03 & 3.56 & 0.36 & 4 & $\mathrm{~F}$ & 9 \\
\hline Camellia spp. & 1459 & 23.78 & $\underline{47.64}$ & 23.99 & 4.46 & 0.14 & 4 & $\mathrm{O}$ & 9 \\
\hline Viburnum spp. & 422 & 15.40 & $\overline{45.02}$ & 35.07 & 3.79 & 0.71 & 4 & $\mathrm{O}$ & 9 \\
\hline Magnolia grandiflora & 220 & 26.36 & 44.55 & 23.64 & 5.00 & 0.45 & 4 & $\mathrm{O}$ & 24 \\
\hline Michelia spp. & 120 & 28.33 & $\underline{44.17}$ & 10.83 & 15.00 & 1.67 & 4 & $\mathrm{O}$ & 9 \\
\hline Acmena spp. & 417 & 19.66 & $\overline{45.08}$ & 20.14 & 10.31 & 4.80 & 4 & $\mathrm{~N}$ & 15 \\
\hline
\end{tabular}

